\title{
Study of Hematological Parameters in Patients with Scorpion Envenomation Presented to the Poison Control Center of Ain Shams University Hospitals
}

\author{
Asmaa Mohamed Magdy Nour Eldin, Mahmoud Lotfy Sakr, Aya Shawky Khater ${ }^{1}$ \\ ${ }^{1}$ Department of Forensic Medicine and Clinical Toxicology, Faculty of Medicine-Ain Shams University, Cairo Egypt.
}

\begin{abstract}
Background: Scorpion envenomation constitutes a genuine problem of public health all over the world, especially in North-Saharan Africa. Aim: To evaluate alterations in hematological parameters correlated to the severity of scorpion envenomation and to assess the relation between these alterations and antivenin therapy. Methods: A prospective study included 36 patients presented to the Poison Control Center of Ain Shams University Hospitals (PCCASUH) with history of scorpion envenomation, from the first of May 2018 to the end of May 2019. Patients were classified into two groups according to the severity of envenomation: Group I (mild envenomation) and Group II (moderate and severe envenomation). Results: Patients presented with moderate and severe envenomation showed increase in hemoglobin level, hematocrit value (Hct) and total leukocytic count (TLC) when compared to those with mild envenomation. Increase of the platelet distribution width (PDW), mean platelet volume (MPV), and platelet large cell ratio (P-LCR) was observed among the patients with moderate and severe envenomation when compared to those with mild envenomation. Decrease of the platelet count and plateletcrit (PCT) was observed among patients with moderate and severe envenomation when compared to those with mild envenomation. Hematocrit value, TLC, platelet count, PCT and activated partial thromboplastin time (APTT) were lower in patients with moderate and severe envenomation after antivenom therapy. Conclusion: Our findings showed that TLC, PLCR and APTT seem to be useful tools in predicting the severity of scorpion envenomation. Hematocrit value, TLC, platelet count, PCT and APTT were useful tools to follow up the patient's condition.

Received in original form: 11 October 2021 Accepted in a final form: 9 November 2021

Key words Hematological, scorpion envenomation, severity
\end{abstract}

\section{Introduction}

corpion envenomation constitutes a genuine problem of public health all over the world, $\checkmark$ especially in North-Saharan Africa. Victims such as children and the elderly who suffer from respiratory and/or cardiovascular diseases become at high risk after scorpion envenomation if not managed adequately and quickly (Santos et al., 2016 \& Abd El-Aziz et al., 2019).

Biologically active substances existing in scorpion venom are involved in severe and often fatal clinical complications; as scorpion venom constitutes a mixture of cardiotoxins, nephrotoxins, hemolytic toxins, and neurotoxins (Cesaretli and Ozkan, 2010 \& Abd El-Aziz et al., 2019).

The balance between pro-inflammatory and anti-inflammatory cytokines released by the host in varying proportions according to the different species of scorpions regulate the extent of inflammation, resulting in major clinical effects such as cardiac dysfunction, pulmonary oedema and shock (Petricevich, 2010).
Severe envenomation is associated with morbidity and mortality which in turn have impact on hospitalization and increased costs (Horoz et al., 2020).

Platelet indices (PCT, PDW and MPV) are reported to be markers of platelet activation which can be altered in different inflammatory diseases (Konca et al., 2014). Studies have been conducted with the help of hematological parameters, especially, the total and differential leukocytic count together with platelet indices as potential new biomarkers to predict the worse clinical course of scorpion envenomation or other diseases as cancer, infectious diseases, cardiovascular diseases, and immunologic diseases (Horoz et al., 2020).

\section{Aim of the Study}

The current study aimed to evaluate the possible alterations in the platelet indices and components of complete blood picture and their correlations to the severity of scorpion envenomation. In addition, it 
assesses the relation between these hematological alterations and antivenin therapy.

\section{Patients and Methods}

\section{Patients}

A prospective cohort study included 36 patients of both sexes presented to the Poison Control Center of Ain Shams University Hospitals (PCC-ASUH) with history of scorpion envenomation within 24 hours, from the first of May 2018 to the end of May 2019. The diagnosis of envenomation was based on history of scorpion sting or scorpion seen in the vicinity by the patient or near family members.

Exclusion criteria: patients presented with delay time more than 24 hours or those who received any previous treatment before reaching the PCC-ASUH. Also patients with previous hematological or inflammatory diseases that may affect the measured parameters as (chronic inflammatory disorders, acute bacterial infection, autoimmune diseases, or anemia).

\section{Ethical consideration}

An informed written consent was obtained from each patient or from his/her guardian in addition to approval of the head of PCC-ASUH and the Research Ethical Committee of Ain Shams University.

\section{Methods}

Patients were classified regarding the severity of envenomation according to the Scorpion Consensus Expert Group (Khattabi et al., 2011) into two groups. Group I (mild envenomation): presented with local manifestations only. Group II (moderate and severe envenomation); moderate envenomation included patients with minor nonlife threatening systemic manifestations. Severe envenomation included patients with severe life-threatening manifestations, together with the presence of at least one of these signs; cardiogenic failure, respiratory failure or neurological failure.

Collected clinical data included demographics (age, sex, residence), site of the sting, delay time (time elapsed between the exposure and arrival to the PCCASUH), clinical assessment (neurological, pupil, respiratory, cardiovascular, gastrointestinal, genitourinary, and skin examination). Investigations included electrocardiogram (ECG) and laboratory investigation which were measured on admission and six hours later.

The laboratory investigations included hemoglobin concentration $(\mathrm{Hb})$, hematocrit value (Hct), total and differential white blood cell count (WBCs), platelets count and platelet indices (platelets distribution width, mean platelet volume, platelet large cell ratio and plateletcrit) measured using Sysmex XN$1000^{\mathrm{TM}}$ Hematology Analyzer (Bates, 2017). Prothrombin time (PT) and activated partial thromboplastin time (APTT) were measured using STA Compact Max ${ }^{\circledR}$ (Laffan and Manning 2017).

According to the PCC-ASUH protocol, all asymptomatic cases were kept under observation for six hours for appearance of any systemic manifestations of scorpion envenomation that necessitate their admission. Asymptomatic patients and patients with local symptoms responding to symptomatic treatment were discharged. Patients with moderate scorpion envenomation were admitted to the inpatient department, while patients with severe scorpion envenomation were transferred to the intensive care unit (I.C.U). Treatment with polyvalent antivenom was conducted to all admitted patients guided by the patients' clinical condition. Inotropic drugs, intubation and mechanical ventilation were used in severe cases of scorpion envenomation.

\section{Statistical analysis}

The results were statistically analyzed using SPSS (Statistical package for Social Science) version 20 software. Mean, standard deviation $( \pm \mathrm{SD})$ and range were calculated for numerical data. Student (t) test was used to analyze normally distributed quantitative variables. Chi-square $\left(\mathrm{X}^{2}\right)$ test was used as a test of significance for qualitative variables presented as number and percentages (Ali and Bhaskar, 2016). Receiver Operating Characteristic (ROC) curve was used to determine the sensitivity and specificity of the investigated hematological parameters to be used as a predictor for severity.

\section{Results}

Thirty-six patients were classified into two groups regarding the severity of scorpion envenomation. Group I: included 17 patients with mild envenomation. Group II: included 18 patients with moderate envenomation, together with one patient with severe envenomation.

Demographics \& intoxication data: The mean age of patients was $29.65 \pm 13.62$ years in group I (mild envenomation) and $29.68 \pm 14.79$ years in group II (moderate and severe envenomation). Male predominance was observed in each studied group. Most of the stings $(70.6 \%)$ and $(78.9 \%)$ in group I, II respectively were found in lower limbs with no stings were observed in head, neck or trunk in both groups. The mean delay time was higher in group II $(2.42 \pm$ 1.34) hours when compared with group I $(2.15 \pm 1.32)$ hours as presented in table (1). The highest percentage of patients came from Mansheyet Naser (25\%) followed by El-Diwea (19.4\%) as presented figure (1).

Clinical manifestations: The mean values of systolic and diastolic blood pressure, pulse rate, and respiratory rate were significantly higher in group II when compared with group I. While the mean value of temperature was significantly lower in group II when compared with group I as demonstrated in table (2).

All cases of group I had no neurological manifestations. On comparing group II and group I, significant difference was found regarding headache and anxiety. All patients of group I had normal size of pupils, equally reacted to light. While, (94.7\%) of patients in group II had dilated pupil equally reacted to light which was statistically significant when compared to group I. Significant difference was observed in patients of group II regarding the occurrence of vomiting and sialorrhea when compared to group I. Pain at the sting site was the only symptom observed in 
(41.2\%) of the patients in group I. Significant difference was found in patients of group II regarding the pain at the sting site when compared to group I as shown in table (3).

Laboratory findings: Significant increase in hemoglobin level, hematocrit value and total leukocytic count was found in the patients of group II when compared to those of group I. Increase of the platelet distribution width, mean platelet volume, and platelet large cell ratio was observed in patients of group II when compared to group I. In group II, patients showed decrease in platelet count and plateletcrit when compared to patients of group I. Patients of group II also showed statistically significant increase in the APTT when compared to group I as presented in table (4).
Significant decrease in hematocrit value, total leukocytic count, neutrophils, platelet count, PCT and APTT were observed in group II after antivenom therapy as shown in table (5). Total leukocytic count showed the highest sensitivity in differentiating between the grades of severity of scorpion envenomation followed by P-LCR and APTT as shown figure (2).

Tachycardia, and elevated ST segment showed statistical difference among the patients of group II when compared to group I as shown in table (6).

Hospital disposition and outcome: forty-seven $\%$ of patients were observed and discharged from the emergency room while $50 \%$ of patients were treated in the inpatient department. Only one patient required admission in the ICU as shown in table (7). All the patients were discharged with complete recovery with no morbidity or mortality.

Table (1): Independent t-test \& Chi-square test statistical analysis of the demographics data (Age-Sex) and intoxication data (Delay time - Anatomical site of sting) among 36 scorpion stung patients groups I (mild envenomation) and group II (moderate and severe envenomation).

\begin{tabular}{|c|c|c|c|c|c|}
\hline & & Group I & Group II & \multirow{2}{*}{ Test value } & \multirow{2}{*}{$P$ - value } \\
\hline & & $\mathbf{N}=17$ & $\mathbf{N}=19$ & & \\
\hline Age (years) & $\begin{array}{c}\text { Mean } \pm \text { SD } \\
\text { Range }\end{array}$ & $\begin{array}{c}29.65 \pm 13.62 \\
16-52\end{array}$ & $\begin{array}{c}29.68 \pm 14.79 \\
16-60\end{array}$ & $-0.008^{\#}$ & $0.994 *$ \\
\hline Sex & $\begin{array}{c}\text { Females } \\
\text { Males }\end{array}$ & $\begin{array}{l}8(47.1 \%) \\
9(52.9 \%) \\
\end{array}$ & $\begin{array}{c}6(31.6 \%) \\
13(68.4 \%) \\
\end{array}$ & $0.905^{* *}$ & $0.342 *$ \\
\hline Delay time (hours) & Mean \pm SD & $2.15 \pm 1.32$ & $2.42 \pm 1.34$ & $-0.618^{\#}$ & $0.541 *$ \\
\hline \multirow{2}{*}{$\begin{array}{l}\text { Anatomical } \\
\text { site of sting }\end{array}$} & Lower limb & $12(70.6 \%)$ & $15(78.9 \%)$ & \multirow{2}{*}{$0.334 * *$} & \multirow{2}{*}{$0.563 *$} \\
\hline & Upper limb & $5(29.4 \%)$ & $4(21.1 \%)$ & & \\
\hline
\end{tabular}

$N=$ number, $S D=$ standard deviation, ${ }^{*}$ Non-significant; P-value $>0.05^{\#}$ Independent Student's T-Test, ${ }^{* *}$ Chi-square test

Table (2): Independent t-test statistical analysis of the vital data among 36 scorpion stung patients.

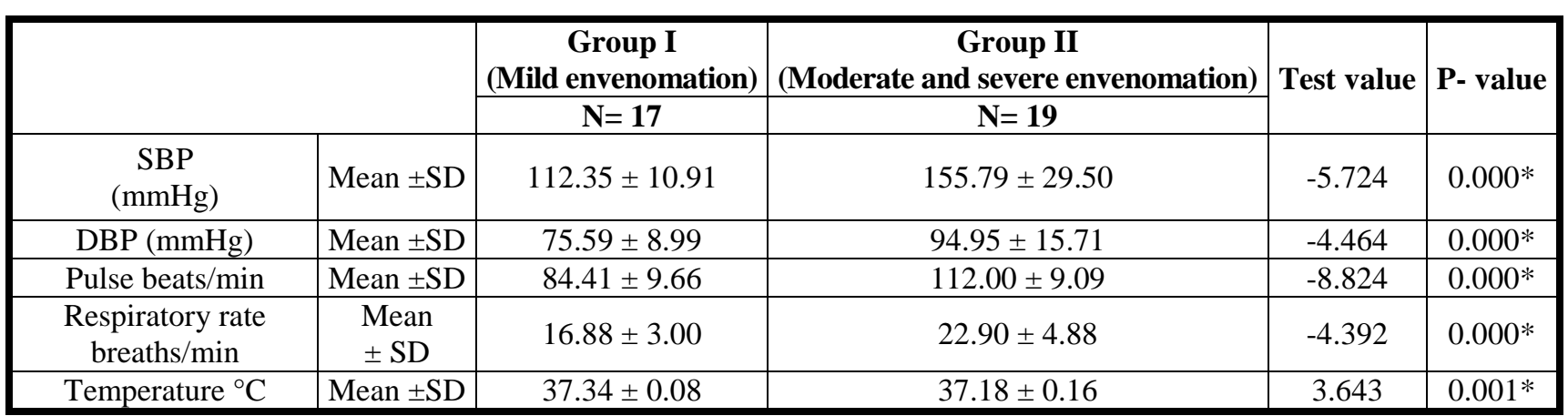

$N$ : number, SBP: systolic blood pressure, SD: standard deviation, DBP: diastolic blood pressure, min: Minute, * highly significant; $P$-value $<0.01$ 
Table (3): Chi-square test statistical analysis of the clinical manifestations among 36 scorpion stung patients.

\begin{tabular}{|c|c|c|c|c|c|c|c|}
\hline & \multicolumn{2}{|c|}{$\begin{array}{l}\text { Group I } \\
\text { (Mild envenomation) } \\
\qquad \mathrm{N}=17\end{array}$} & \multicolumn{2}{|c|}{$\begin{array}{c}\text { Group II } \\
\text { (Moderate and severe } \\
\text { envenomation) } \\
\mathrm{N}=\mathbf{1 9}\end{array}$} & \multirow[t]{2}{*}{ Test value } & \multirow[t]{2}{*}{ P- value } & \multirow[t]{2}{*}{ Sig } \\
\hline & No. & $\%$ & No. & $\%$ & & & \\
\hline $\begin{array}{l}\text { - Neurological manifestations } \\
\text { Coma } \\
\text { Headache } \\
\text { Anxiety } \\
\text { Agitation } \\
\text { Convulsion }\end{array}$ & $\begin{array}{l}0 \\
0 \\
0 \\
0 \\
0\end{array}$ & $\begin{array}{l}0.0 \% \\
0.0 \% \\
0.0 \% \\
0.0 \% \\
0.0 \% \\
\end{array}$ & $\begin{array}{l}1 \\
4 \\
4 \\
1 \\
1\end{array}$ & $\begin{array}{c}5.3 \% \\
21.1 \% \\
21.1 \% \\
5.3 \% \\
5.3 \% \\
\end{array}$ & $\begin{array}{l}0.920 \\
4.026 \\
4.026 \\
0.920 \\
0.920 \\
\end{array}$ & $\begin{array}{l}0.337 \\
0.045 \\
0.045 \\
0.337 \\
0.337 \\
\end{array}$ & $\begin{array}{c}\text { NS } \\
\text { S } \\
\text { S } \\
\text { NS } \\
\text { NS }\end{array}$ \\
\hline $\begin{array}{l}\text { - Eye examination } \\
\text { Normal size } \\
\text { Dilated reactive } \\
\end{array}$ & $\begin{array}{c}17 \\
0 \\
\end{array}$ & $\begin{array}{l}100 \% \\
0.0 \% \\
\end{array}$ & $\begin{array}{c}1 \\
18 \\
\end{array}$ & $\begin{array}{l}5.3 \% \\
94.7 \% \\
\end{array}$ & 32.211 & 0.000 & S \\
\hline $\begin{array}{l}\text { - Respiratory system examination } \\
\text { Respiratory distress } \\
\text { Acute pulmonary edema }\end{array}$ & $\begin{array}{l}0 \\
0 \\
\end{array}$ & $\begin{array}{l}0.0 \% \\
0.0 \% \\
\end{array}$ & $\begin{array}{l}1 \\
1 \\
\end{array}$ & $\begin{array}{l}5.3 \% \\
5.3 \% \\
\end{array}$ & $\begin{array}{l}0.920 \\
0.920 \\
\end{array}$ & $\begin{array}{l}0.337 \\
0.337 \\
\end{array}$ & $\begin{array}{l}\text { NS } \\
\text { NS }\end{array}$ \\
\hline $\begin{array}{l}\text { - Cardiovascular manifestations } \\
\text { cardiovascular collapse }\end{array}$ & 0 & $0.0 \%$ & 1 & $5.3 \%$ & 0.920 & 0.337 & NS \\
\hline $\begin{array}{l}\text { - Gastrointestinal manifestations } \\
\text { Sialorrhea } \\
\text { Vomiting }\end{array}$ & $\begin{array}{l}0 \\
0\end{array}$ & $\begin{array}{l}0.0 \% \\
0.0 \%\end{array}$ & $\begin{array}{l}19 \\
19 \\
\end{array}$ & $\begin{array}{l}100.0 \% \\
100.0 \%\end{array}$ & $\begin{array}{l}36.00 \\
36.00\end{array}$ & $\begin{array}{l}0.000 \\
0.000\end{array}$ & $\begin{array}{l}S \\
S\end{array}$ \\
\hline $\begin{array}{l}\text { - Genitourinary manifestations } \\
\text { Oliguria } \\
\text { Priapism }\end{array}$ & $\begin{array}{l}0 \\
0\end{array}$ & $\begin{array}{l}0.0 \% \\
0.0 \% \\
\end{array}$ & $\begin{array}{l}1 \\
1\end{array}$ & $\begin{array}{l}5.3 \% \\
5.3 \% \\
\end{array}$ & $\begin{array}{l}0.920 \\
0.920 \\
\end{array}$ & $\begin{array}{l}0.337 \\
0.337 \\
\end{array}$ & $\begin{array}{l}\text { NS } \\
\text { NS }\end{array}$ \\
\hline $\begin{array}{l}\text { - Skin examination } \\
\text { Local pain }\end{array}$ & 7 & $41.2 \%$ & 19 & $100.0 \%$ & 15.475 & 0.000 & S \\
\hline
\end{tabular}

N: number, \%: percentage, P-value >0.05: Non-significant (NS); P-value <0.05: Significant (S). 
Table (4): Independent t-test statistical analysis of the initial hematological values among 36 scorpion stung patients.

\begin{tabular}{|c|c|c|c|c|c|c|}
\hline & \begin{tabular}{|c|} 
Group I \\
(Mild envenomation)
\end{tabular} & $\begin{array}{c}\text { Group II } \\
\text { (Moderate and severe envenomation) }\end{array}$ & \multirow[t]{2}{*}{ Test value } & \multirow[t]{2}{*}{ P-value } & \multirow[t]{2}{*}{ Sig. } \\
\hline & & $\mathrm{N} .=17$ & $N_{.}=19$ & & & \\
\hline $\mathrm{Hb}(\mathrm{g} / \mathrm{dL})$ & Mean \pm SD & $12.69 \pm 1.71$ & $13.93 \pm 1.60$ & -2.244 & 0.031 & $\mathrm{~S}$ \\
\hline Hct $(\%)$ & Mean \pm SD & $37.91 \pm 4.78$ & $41.50 \pm 5.69$ & -2.038 & 0.049 & $\mathrm{~S}$ \\
\hline $\mathrm{TLC}(/ \mu \mathrm{L})$ & Mean \pm SD & $7.47 \pm 2.85$ & $10.41 \pm 3.26$ & -2.865 & 0.007 & HS \\
\hline Neutrophils $(/ \mu \mathrm{L})$ & Mean \pm SD & $5.41 \pm 3.16$ & $7.10 \pm 3.08$ & -1.627 & 0.113 & NS \\
\hline Lymphocytes $(/ \mu \mathrm{L})$ & Mean \pm SD & $1.67 \pm 0.70$ & $2.47 \pm 0.99$ & -2.763 & 0.009 & HS \\
\hline Monocytes $(/ \mu \mathrm{L})$ & Mean \pm SD & $0.41 \pm 0.31$ & $0.67 \pm 0.37$ & -2.239 & 0.032 & $\mathrm{~S}$ \\
\hline Eosinophils $(/ \mu \mathrm{L})$ & Mean \pm SD & $0.10 \pm 0.08$ & $0.08 \pm 0.12$ & 0.535 & 0.596 & NS \\
\hline Basophils $(/ \mu \mathrm{L})$ & Mean \pm SD & $0.05 \pm 0.05$ & $0.05 \pm 0.07$ & -0.054 & 0.957 & NS \\
\hline Platelet count $(/ \mu \mathrm{L})$ & Mean \pm SD & $288.06 \pm 71.09$ & $285.37 \pm 76.95$ & 0.109 & 0.914 & NS \\
\hline PDW $(\%)$ & Mean \pm SD & $12.24 \pm 2.01$ & $13.63 \pm 2.11$ & -2.012 & 0.052 & NS \\
\hline MPV (fL) & Mean \pm SD & $10.42 \pm 0.94$ & $11.13 \pm 1.14$ & -2.037 & 0.050 & NS \\
\hline P-LCR (\%) & Mean \pm SD & $24.85 \pm 11.92$ & $33.42 \pm 5.74$ & -2.793 & 0.009 & HS \\
\hline PCT $(\%)$ & Mean \pm SD & $3.70 \pm 9.60$ & $0.33 \pm 0.08$ & 1.536 & 0.134 & NS \\
\hline PT (seconds) & Mean \pm SD & $13.97 \pm 0.88$ & $13.63 \pm 0.81$ & 1.203 & 0.237 & NS \\
\hline APTT (seconds) & Mean \pm SD & $31.07 \pm 2.89$ & $34.91 \pm 4.55$ & -2.982 & 0.005 & HS \\
\hline
\end{tabular}

SD: standard deviation, $N$ : number, Hb: Hemoglobin concentration, g/dL: gram/deciliter, Hct: Hematocrit, $\mu L:$ microlitre, TLC: total leukocytic count, PDW: platelet distribution width, MPV: mean platelet volume, fL: femtoliters, \%: percentage, P-LCR: platelet large cell ratio, PCT: Plateletcrit, PT: prothrombin time, APTT: Activated partial thromboplastin time, Pvalue >0.05: Non-significant (NS); P-value <0.05: Significant (S); P-value< 0.01: highly significant (HS)

Table (5): Paired t-test statistical analysis of the initial hematological values and following antivenom therapy among 19 adult patients with moderate and severe scorpion envenomation

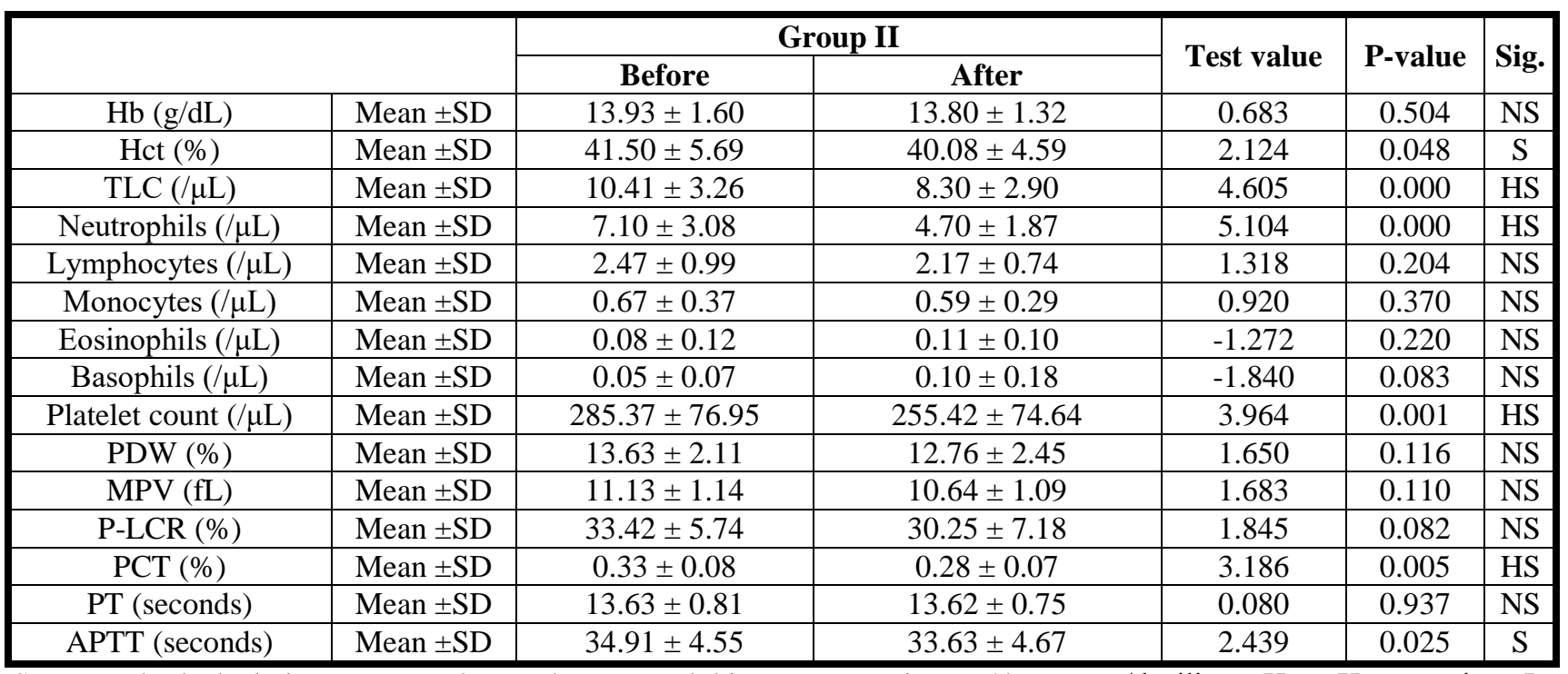

SD: standard deviation, $\mathrm{N}$ : number, Hb: Hemoglobin concentration, g/dL: gram/deciliter, Hct: Hematocrit, $\mu \mathrm{L}$ : microlitre, TLC: total leukocytic count, PDW: platelet distribution width, MPV: mean platelet volume, fL: femtoliters, \%: percentage, P-LCR: platelet large cell ratio, PCT: Plateletcrit, PT: prothrombin time, APTT: Activated partial thromboplastin time, P-value >0.05: Non-significant (NS); P-value <0.05: Significant (S).

Table (6): Chi-square test statistical analysis showing electrocardiographic changes (ECG) in correlation to severity among 36 scorpion stung patients

\begin{tabular}{|c|c|c|c|c|c|c|}
\hline \multirow{2}{*}{} & \multicolumn{2}{|c|}{$\begin{array}{c}\text { Group I } \\
\text { (Mild envenomation) } \\
\text { N.=17 }\end{array}$} & \multicolumn{2}{c|}{$\begin{array}{c}\text { Group II (Moderate and } \\
\text { severe envenomation) } \\
\text { N.= 19 }\end{array}$} & \multirow{2}{*}{ Test value } & \multirow{2}{*}{ P-value } \\
\cline { 2 - 5 } & No. & $\mathbf{\%}$ & No. & \% & & \\
\hline Normal & 17 & $100.0 \%$ & 0 & $0.0 \%$ & \multirow{2}{*}{36.000} & \multirow{2}{*}{$0.000^{*}$} \\
\hline Tachycardia & 0 & $0.0 \%$ & 18 & $94.7 \%$ & \\
\hline ST- segment elevation & 0 & $0.0 \%$ & 1 & $5.3 \%$ & & \\
\hline
\end{tabular}

$N$ : number, \%: percentage, $P$-value $<0.01: *$ highly significant 
Table (7): Hospital disposition among 36 scorpion stung patients

\begin{tabular}{|c|c|c|}
\hline & Number of patients & Percentage of patients \\
\hline Emergency room & 17 & $47 \%$ \\
\hline Inpatient department & 18 & $50 \%$ \\
\hline ICU & 1 & $2.7 \%$ \\
\hline
\end{tabular}

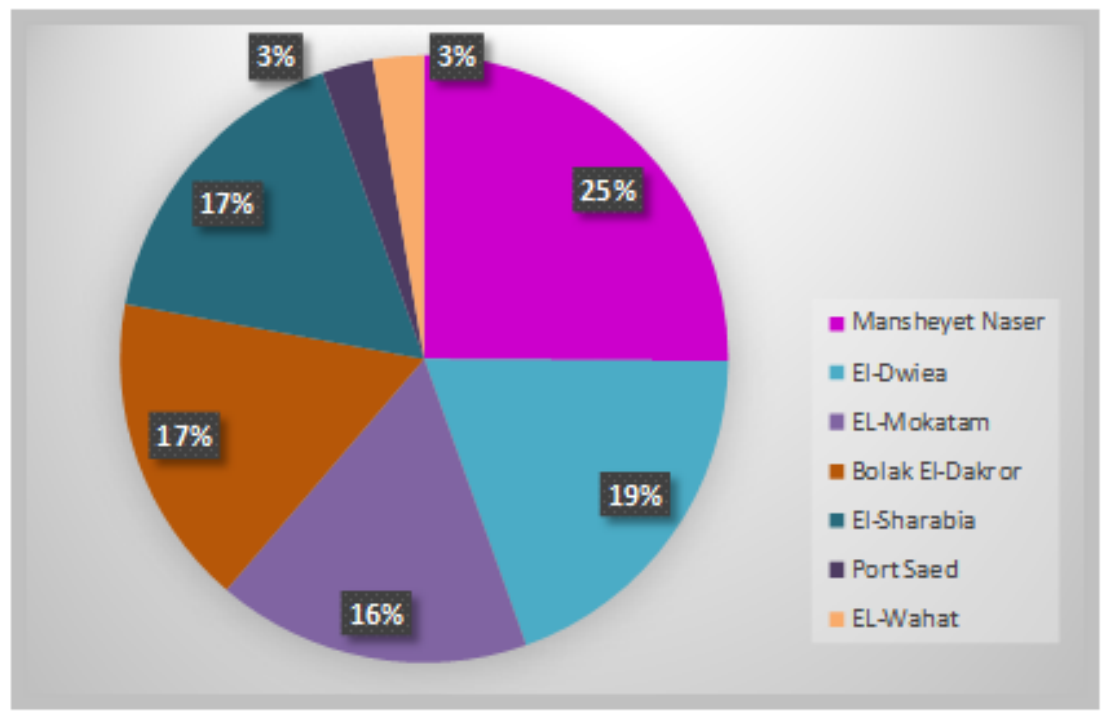

Figure (1): Pie chart showing the distribution of residence among 36 adult patients with scorpion sting.

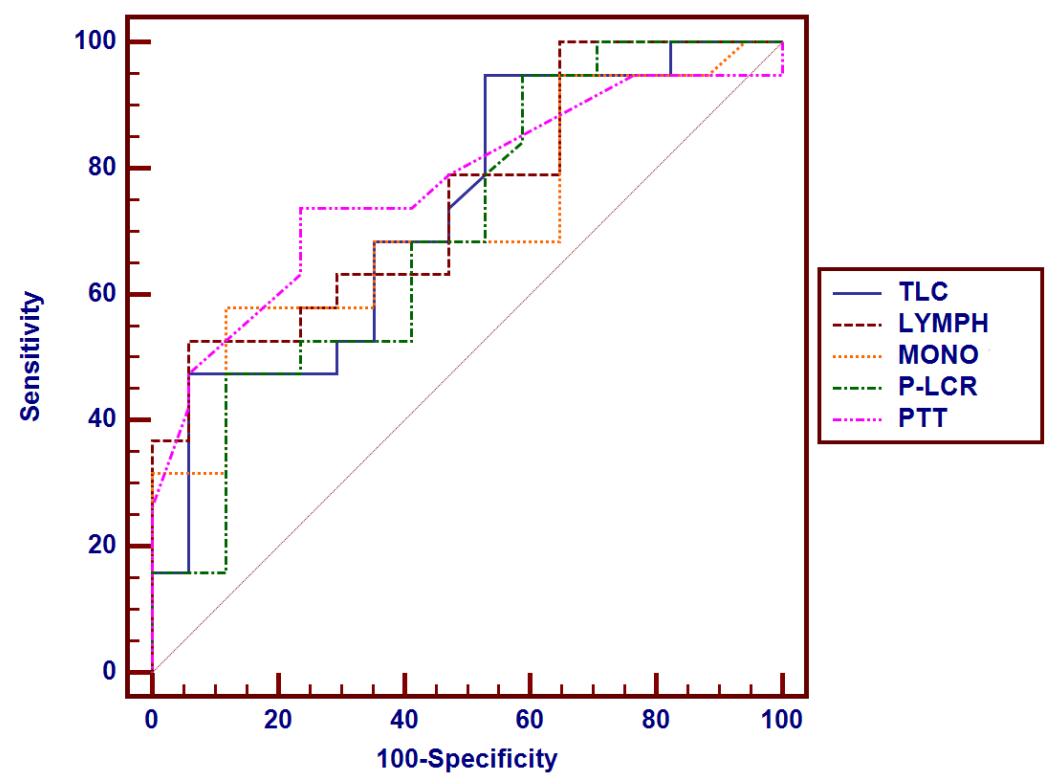

Figure (2): Receiver Operating Characteristic (ROC) Curve for cut-off levels of initial total leucocytic count, Lymphocyte, Monocytes, P-LCR and PTT among 36 adult patients with scorpion sting.

\section{Discussion}

The current study showed that the mean age of patients was $29.65 \pm 13.62$ years in group I (mild envenomation) and $29.68 \pm 14.79$ years in group II (moderate and severe envenomation). The higher incidence of scorpion envenomation in adults was also observed by Baseer and Naser (2019). No significant correlation between the age of the patients and the severity of scorpion envenomation was observed in the current study. This finding was in line with Bosnak et al. (2009a) who explained that this is due to the fact that the mean age of the patients was relatively high in the studied groups. 
Male predominance was observed in both group I and II in the current study. This finding was in accordance with Mohamed et al. (2016) and Ahmed et al. (2018), who reported that males were more liable to exposure to scorpion sting than females. This was attributed to the more outdoor time spent by males than females putting them at more risk for scorpion stings.

In the current study, the mean delay time for group I (mild envenomation) was $(2.15 \pm 1.32)$ hours and $(2.42$ \pm 1.34) hours for group II (moderate and severe envenomation). These findings were in line with $\mathrm{El}$ Asheer et al. (2019) who reported the highest percentage of patients $(60 \%)$ were presented between two to four hours after the scorpion sting. These results were explained by the fact that $90 \%$ of patients in this study were from rural areas taking longer time than urban patients to reach a tertiary referral center after sting.

Most of the stings $(70.6 \%)$ and $(78.9 \%)$ in group I, II respectively were in the lower limbs. No stings were observed in the head, neck, or trunk in both groups. These findings were in parallel to Bosnak et al. (2009 b) and Ganesh and Kumaravel (2016) who found that extremities were the most common body parts stung. The likely reason is that many victims do not use appropriate protective tools such as boots and gloves in the farmlands and dooryard gardens where scorpions are active (Ebrahimi et al., 2017).

Regarding the residence of patients in the current study, the highest percentage of patients were from Mansheyet Naser (25\%). Similar results were observed by Mohammed et al. (2009). This was attributed to the rural nature of the area and its proximity to El-Mokatam Mountain where scorpions are abundant. Also, Chippaux and Goyffon (2008) and El-Asheer et al. (2019) found that higher frequency of envenomation were from rural areas.

The presence of hypertension and tachycardia among patients with moderate and severe envenomation in the current study was in accordance with other studies by Ahmed et al. (2015) and Azab and ELawady (2016). The catecholamine release due to scorpion envenomation cause cardiac arrhythmias, tachycardia, arterial hypertension (Cupo, 2015).

In this study, the mean respiratory rate was significantly higher in group II when compared with group I. This goes in parallel with Azab and ELawady (2016) who reported tachypnea as severe manifestation of scorpion envenomation.

The mean temperature in group II was significantly lower when compared with group I. These findings coincides with the observation by Bouaziz et al. (2008) who reported that $50.2 \%$ of patients had normal body temperature, while hyperthermia was found in $42.3 \%$ of the patients. Thermoregulation disturbances are attributed to massive liberation of cytokines (IL-1alpha, IL 6, IL-10, and TNF alpha) (Mohamad et al., 2014).

In the current study, on comparing group II and group I, there was significant difference regarding headache and anxiety. These findings were in accordance with $\mathrm{Abd}$ El-Aziz et al. (2019) who reported that headache was the commonest neurological symptom among the studied group followed by disturbed conscious level then dizziness. In addition, Mohamad et al. (2014) observed that neurological manifestations were an indicator of severity of scorpion envenomation in $74 \%$ of their patients. Hypertensive encephalopathy, brain ischemia secondary to pulmonary edema and cardiac shock, or direct effect of the venom on the CNS are involved in the pathophysiology of scorpion envenomation.

In the current study, all patients of group I had normal size of pupils and were equally reactive to light. While, (94.7\%) of patients in group II had dilated pupil equally reactive to light which was statistically significant when compared to group I. Bilateral mydriasis was observed by Bouaziz et al. (2008) in $1.7 \%$ of their patients. The authors correlated this finding to the severity of scorpion envenomation. Bilateral mydriasis is due to the autonomic storm induced by scorpion venom as part of the systemic manifestations of scorpion envenomation (Chippaux and Goyffon 2008).

Concerning the gastrointestinal manifestations, vomiting and sialorrhea were observed in all patients of group II which was statistically significant compared to group I. This finding coincides with Abd El-Aziz et al. (2019) who reported that vomiting was the commonest gastrointestinal symptom among their studied group. Serotonin content of venom and transient parasympathetic stimulation after sting are the leading pathophysiology of vomiting.

In the present study, pain at the sting site was the only symptom observed in $(41.2 \%)$ of the patients in group I. Significant difference was found in patients of group II regarding the pain at the sting site when compared to group I. Our findings were conceded with Mohamad et al. (2014) and Azab and ELawady (2016) who reported that the local reaction was the most common presentation in their studied groups. The severe pain observed in scorpion envenomation is attributed to a pain- inducing peptide measured in the venoms of scorpion (Hakim et al., 2015).

In the current study patients of group II (moderate and severe envenomation) showed statistically significant increase in hemoglobin level and hematocrit value when compared to those of group I (mild envenomation). These findings were in accordance with the results of Mohammed et al. (2009) who observed increase in hemoglobin level and hematocrit value in severe cases of scorpion envenomation in their study. Radha and Zare (2002) and Mirakabadi et al. (2006) explained the rise of hemoglobin by hemoconcentration which occurred because of massive release of catecholamines and angiotensin II producing significant decrease in the blood volume and an increase in the extravascular fluid, leading eventually to peripheral circulatory failure and pulmonary edema. On the other side, Emam et al. (2008) found decrease in hemoglobin level among their patients. This was attributed to the action of scorpion venom on the red blood cell membrane causing hemolysis. Hemolysis was not observed in the current study. 
Patients of group II showed statistically significant increase in total leukocytic count when compared to those of group I in the current study. These findings were in accordance with the results of Baseer and Naser (2019) and Horoz et al., (2020)who observed that leukocyte levels were markedly increased in nonsurvivors compared to survivor patients with scorpion envenomation. This was explained by systemic inflammatory response-like syndrome induced by scorpion venom (Borges et al., 2015).

In the current study, patients of group II showed decrease in platelet count when compared to patients of group I. These findings were in accordance with results of Mishal et al. (2015) and Pinto et al. (2010), who observed marked decrease of the platelet count following scorpion envenomation. These findings were explained by Heemskerk et al. (2002) confirming that blood platelets have main role in the regulation of adhesive and coagulation properties. The platelets provide a catalytic surface by assembling the enzymes complexes and accelerate the fibrin formation which leads to pulmonary hemorrhage and thrombocytopenia. However, marked increase in platelet count were observed by Baseer and Naser (2019) in non-survivors compared to survivor patients with scorpion envenomation. The stimulatory effect of released catecholamines, especially adrenaline, on platelet synthesis may be attributed to this increase (Dai et al., 2019).

The correlation between platelet indices and scorpion envenomation was assessed by few studies Konca et al. (2014) and Horoz et al. (2020). The current study demonstrated statistically significant increase of the platelet distribution width, mean platelet volume, and platelet large cell ratio in patients of group II when compared to those of group I. The findings in the current study go with studies by Chandrashekar et al. (2014), Yazici et al. (2010), Turhan et al. (2010) and Yorulmaz et al. (2019) that the MPV value is high in association with the severity of inflammation (chronic urticaria, rheumatoid arthritis, chronic hepatitis B, myocardial infarction, an acute attack of familial Mediterranean fever). This could be explained by the fact that MPV might decrease in high- grade inflammation due to the consumption and sequestration of large platelets in the highly vascular supplied area of the inflammatory region (Budak et al., 2016).

Severe scorpion envenomation is related to an excessive systemic host inflammatory response to stings and it was found that platelets play an important role in the inflammatory response (Trzeciak-Ryczek et al., 2013). Moreover, larger platelets are metabolically and enzymatically more active than smaller platelets (Konca et al., 2014).

However, Konca et al. (2014) observed significant decrease of the mean MPV values for the patients with scorpion envenomation when compared to the control group. These findings were explained by the fact that high- grade inflammatory diseases present with low levels of MPV, but low-grade inflammatory conditions present with high levels of MPV ( Yuri Gasparyan et al., 2011).
Platelet distribution width (PDW) is a direct flow-cytometric measurement of platelet cell volume, as PDW is measured at $20 \%$ relative height of the total height of the curve, depicting their distribution. An increased PDW is an indication of the anisocytosis and activation of platelets (Vagdatli et al., 2010). An increased level of PDW has been measured with inflammation in many diseases. Horoz et al., (2020) observed that the PDW values of their patients who were admitted due to scorpion envenomation, were found to be statistically significantly higher than the control group in their study.

Platelet larger cell ratio (P-LCR) is an indicator of circulating larger platelets ( $>12 \mathrm{fL})$ and has been used to monitor platelet activity (Hong et al., 2014). The findings in the current study were in line with Grotto and Noronha (2004) who observed that larger platelets are more frequent in patients with abnormalities in lipid profile. Since, larger platelets are more reactive, so they contribute to the increased risk for cardiovascular disease.

Plateletcrit is another platelet index that is a reliable measurement of platelet bio-mass, because it combines the MPV with the absolute platelet count (Akpinar et al., 2014). Decrease in plateletcrit was observed in the patients of group II when compared to patients of group I in the present study. These findings go in line with Konca et al., (2014) who concluded that the mean PCT values in the patients with scorpion evenmonation were lower than in their control group.

Patients of group II showed statistically significant increase in the APTT when compared to in group I. Similar results were observed by Köse et al. (2016), which was explained by the fact that stimulation of chemical mediators (neurotransmitters, catecholamines) and release of cytokines and inflammatory mediators were involved in hepatic and hematologic derangement.

This study showed that hematocrit value, total leukocytic count, neutrophils, platelet count, PCT and APTT were significantly lower in group II after antivenom therapy. The current study showed that total leukocytic count had the highest sensitivity in differentiating between the grades of severity of scorpion envenomation, followed by $P-L C R$ and $A P T T$.

The current study shows that all of patients of group I had normal ECG recordings compared to patients of group II who showed abnormal ECG recordings in the form of rhythm abnormalities like tachycardia in $94.7 \%$ of patients and ST segment elevation in $5.3 \%$ of patients. These findings were in accordance with Çağlar et al. (2015) who observed that sinus tachycardia was the most common dysrhythmia, in their study. Voltage-gated sodium and potassium channels are affected by scorpion venom in addition to myocardial ischemia. Additionally, hyperglycemia and hypokalemia can cause electrocardiographic changes.

The current study shows that all the patients were discharged with complete recovery with no morbidity or mortality. These findings were also observed by Ganesh and Kumaravel (2016) observing that there was no mortality due to scorpion 
envenomation during their study period. These findings together with hospital disposition could be explained by the fact of the availability of anti-venom and strict guidelines concerning these exposures emergencies in PCC-ASUH and non-aggressive species especially in scorpion El Masry and Tawfik (2013).

The main limitation of the present study was the small sample size which led to insignificance of the differences in some of measured hematological parameters.

\section{Conclusion}

In conclusion, our study demonstrated that scorpion envenomation may lead to variable alterations in hematological parameters and platelet indices. That total leukocytic count had the highest sensitivity in differentiating between the grades of severity of scorpion envenomation, followed by P-LCR and APTT. Complete blood picture with differential count, platelet indices and APTT can be useful and simple tools in predicting the severity of scorpion envenomation and following up the effect of treatment in moderate and severe scorpion envenomation. Further trials including increased number of samples are needed to confirm the results.

\section{References}

Abd El-Aziz, F. E. -Z. A., El Shehaby, D. M., Elghazally, S. A., et al. (2019): Toxicological and epidemiological studies of scorpion sting cases and morphological characterization of scorpions (Leiurusquin questriatus and Androctonus crassicauda) in Luxor, Egypt. Toxicology Reports, 6: 329-35.

Ahmed, A. E., Abdel-Baseer, K. A., Saad, K., et al. (2015): Endocrinological and biochemical changes of scorpionism in children in Upper Egypt. Therapeutic Advances in Endocrinology and Metabolism, 6(5): 210-6.

Ahmed, A. E. A., Hassan, M. H., Rashwan, N. I., et al. (2018): Myocardial injury induced by scorpion sting envenoming and evidence of oxidative stress in Egyptian children. Toxicon, 153: 72-77.

Ali, Z., and Bhaskar, S. B. (2016): Basic statistical tools in research and data analysis. Indian $J$ Anaesth, 60:662-9.

Akpinar I, Sayin MR, Gursoy YC, et al. (2014) Plateletcrit: a platelet marker associated with saphenous vein graft disease. Herz, 39:142-8.

Azab, G., and ELawady, E. (2016): Some Biochemical Parameters as a Simple Tool for the Prediction of Severity of Scorpion Envenomation among Some Egyptian Children. Ain Shams Journal of Forensic Medicine and Clinical Toxicology, 26(1): 95-104.

Baseer, K. A., and Naser, M. A. A. (2019): Predictors for mortality in children with scorpion envenomation admitted to pediatric intensive care unit, Qena Governorate, Egypt. Am. J. Trop. Med. Hyg., 101(4): 941-45.

Bates, I. (2017): Reference Ranges and Normal Values. In B. J. Bain, I. Bates, M. A. Laffan (Eds.),
Dacie and Lewis Practical Haematology $\left(12^{\text {th }}\right.$ ed.,). Elsevier,China. pp.8-17

Borges, A., Morales, M., Loor, W., et al. (2015): Scorpionism in Ecuador: First report of severe and fatal envenoming cases from northern Manabí by Tityus asthenes Pocock. Toxicon, 105: 56-61.

Bouaziz, M., Bahloul, M., Kallel, H., et al. (2008): Epidemiological, clinical characteristics and outcome of severe scorpion envenomation in South Tunisia: Multivariate analysis of 951 cases. Toxicon, 52(8): 918-26.

Bosnak, M., Ece, A., Yolbas, I., et al. (2009a): Scorpion sting envenomation in children in southeast Turkey. Wilderness and Environmental Medicine, 20(2): 118-24.

Bosnak, M., Levent Yilmaz, H., Ece, et al. (2009b): Severe scorpion envenomation in children: Management in pediatric intensive care unit. Human and Experimental Toxicology, 28(11): 721-8.

Budak, Y. U., Polat, M., and Huysal, K. (2016): The use of platelet indices, plateletcrit, mean platelet volume and platelet distribution width in emergency non-traumatic abdominal surgery: A systematic review. Biochemia Medica, 26(2): 178-93.

Çağlar, A., Köse, H., Babayitit, A., et al. (2015): Predictive Factors for Determining the Clinical Severity of Pediatric Scorpion Envenomation Cases in Southeastern Turkey. Wilderness \& Environmental Medicine, 26(4): 451-8.

Cesaretli, Y., and Ozkan, O. (2010): Scorpion stings in Turkey: Epidemiological and clinical aspects between the years 1995 and 2004. Rev. Inst. Med. Trop. Sao Paulo, 52(4): 215-20.

Chandrashekar, L., Rajappa, M., Sundar, I., et al. (2014): Platelet activation in chronic urticaria and its correlation with disease severity. Platelets, 25(3): 162-5.

Chippaux, J. P., and Goyffon, M. (2008): Epidemiology of scorpionism: A global appraisal. Acta Tropica, 107(2): 71-9.

Cupo, P. (2015): Clinical update on scorpion envenoming. Rev Soc Bras Med Trop, 48(6): 642-9.

Dai, Y., Huo, X., Cheng, Z., et al. (2019): Alterations in platelet indices link polycyclic aromatic hydrocarbons toxicity to low-grade inflammation in preschool children. Environment International, 131(March), 105043:1-10.

Ebrahimi, V., Hamdami, E., Moemenbellah-Fard, M. D., et al. (2017): Predictive determinants of scorpion stings in a tropical zone of south Iran: Use of mixed seasonal autoregressive moving average model. Journal of Venomous Animals and Toxins Including Tropical Diseases, 23(1): $1-13$.

El-Asheer, O. M., Hammad, E. E. M., Mohamad, I. L., et al. (2019): A randomized comparative study between intravenous and intramuscular scorpion 
antivenom regimens in children. Toxicon, 159 : 45-9.

El Masry, M., \& Tawfik, H. (2013). 2011 Annual Report of the Poison Control Centre of Ain Shams University Hospital, Cairo, Egypt. Ain Shams Journal of Forensic Medicine and Clinical Toxicology, 20(1), 10-7.

Emam, S.J.; Khosravi, A.D. and Almohammad, A. (2008): Evaluation of hematological and urine parameters in Hemiscorpius Lepturus (Gadim) victims referred to Razi hospital, Ahwaz, Iran. J.Med.Sci.;8(3):306-9.

Ganesh, J., and Kumaravel, S. (2016): A study on the clinical profile of scorpion envenomation in children. International Journal of Contemporary Pediatrics, 3(1): 125-8.

Grotto, H. Z. W., and Noronha, J. F. A. (2004): Platelet larger cell ratio (P-LCR) in patients with dyslipidemia. Clinical \& Laboratory Haematology, 26(5): 347-9.

Hakim MA, Jiang W, Luo L, et al. (2015): Scorpion Toxin, BmP01, Induces Pain by Targeting TRPV1 Channel. Toxins (Basel). 14;7(9):3671-87.

Heemskerk, J. W., Bevers, E. M. and Lindhout, T., (2002): Platelet activation and blood coagulation. Thromb. Haemost., 88: 186-93.

Hong, H., Xiao, W., and Maitta, R. W. (2014): Steady increment of immature platelet fraction is suppressed by irradiation in single-donor platelet components during storage. PLoS One, 9(1), e85465.

Horoz, Ö. Ö., Yıldızdaş, D., Aslan, N. et al. (2020): Is there any relationship between initial hematological parameters and severity of scorpion envenomation? Turk J Pediatr, 62(3): 394-404.

Konca, C., Tekin, M., Colak, P., et al. (2014): An overview of platelet indices for evaluating platelet function in children with scorpion envenomation. EXCLI Journal, 13: 801-8.

Khattabi, A., Soulaymani-Bencheikh, R., Achour, S., et al. (2011): Classification of clinical consequences of scorpion stings: Consensus development. Transactions of the Royal Society of Tropical Medicine and Hygiene, 105(7): 364-9.

Köse, A., Biricik, S., Bozkurt, S., et al. (2016): Annuals of Clinical Case Reports Toxic Hepatitis and Coagulopathy due to Scorpion Sting. Annuals of Clinical Case Reports Emergency Medicine, 1: 1-3.

Laffan M. A. and Manning R. A. (2017): Investigation of Haemostasis. In B. J. Bain, I. Bates, M. A. Laffan,.. [et Al.] (Eds.), Dacie and Lewis Practical Haematology (12 ${ }^{\text {th }}$ ed., pp.366-409). Elsevier,China.

Mirakabadi, A.Z.; Jalali, A.; Jahromi, A.E.; Vatanpur, H. and Akbary, A. (2006): Biochemical changes and manifestations of envenomation produced by Odonthobuthus doriae venom in rabbits. J. Venom. Anim. Toxins incl. Trop. Dis., 12, (1): 67-77.
Mohamad, I. L., Elsayh, K. I., Mohammad, H. A., et al. (2014): Clinical characteristics and outcome of children stung by scorpion. European Journal of Pediatrics, 173(6): 815-8.

Mohamed, H.Y., Badr, R.E., Seif El-din, M., et al. (2016): Cardiac biomarkers assay for early detection of toxic myocarditis following scorpions stings exposure. J. Am. Sci., 12, 7-23.

Mohammed, R. H., Abd El Messih, M. S., Ramadan, M. M., et al. (2009): Assessment of the Possible Role of Some Laboratory Parameters in Early Diagnosis of Pulmonary Edema Secondary to Scorpion Envenomation, (Unpublished master's thesis). Ain Shams University, Cairo, Egypt.

Mishal, R., Tahir, H. M., Yaqoob, R., Zafar, K., Arshad, M., \& Sher, M. (2015). Haematological effects of odontobuthus odonturus (Arachnida: Buthidae) venom in albino mice. Pakistan Journal of Zoology, 47(5), 1213-8.

Petricevich, V. L. (2010): Scorpion venom and the inflammatory response. Mediators of Inflammation, 2010.

Pinto, M. C. L., Melo, M. M., Costa, M. E. R., \& Labarrere, C. R. (2010). Hematological and biochemical profiles of rats submitted to experimental poisoning with Tityus serrulatus venom. Arquivo Brasileiro de Medicina Veterinaria e Zootecnia, 62(2), 350-6.

Radha, K.M. and Zare, M.A. (2002): Scorpion antivenom reverses metabolic,electrocardiographic and hormonal disturbances caused by the Indian red scorpion Mesobuthus tamulus concanesis, Pocock envenomation. J.Venom Anim. Toxins, 8:1-4.

Santos, M. S. V., Silva, C. G. L., Neto, B. S., et al. (2016): Clinical and Epidemiological Aspects of Scorpionism in the World: A Systematic Review. Wilderness \& Environmental Medicine, 27(4): 504-18.

Trzeciak-Ryczek, A., Tokarz-Deptuła, B., and Deptuła, W. (2013): Platelets - an important element of immune system. Journal of Veterinary Sciences. 16(2): 407-3.

Turhan O, Coban E, Inan D, et al. (2010): Increased mean platelet volume in chronic hepatitis B patients with inactive disease. Med Sci Monit, 16: CR202-5.

Vagdatli, E., Gounari, E., Lazaridou, E., et al. (2010): Platelet distribution width: a simple, practical and specific marker of activation of coagulation. Hippokratia, 14(1): 28.

Yazici S, Yazici M, Erer B, et al. (2010): The platelet indices in patients with rheumatoid arthritis: mean platelet volume reflects disease activity. Platelets, 21 (2): 122-5.

Yorulmaz A, Akbulut H, Taş SA, et al. (2019): Evaluation of hematological parameters in children with FMF. Clin Rheumatol, 38: 701- 7.

Yuri Gasparyan, A., Ayvazyan, L., P Mikhailidis, D., et al. (2011): Mean platelet volume: a link between thrombosis and inflammation?. Current pharmaceutical design, 17(1): 47-58. 


\title{
دراسة دلالات الام لاى مرضي لاغات العقارب بمركز السموم الإكلينيكي بمستشفيات جامعة عين شمس
}

\author{
أسماء محمد بجدي نور الدين ومحمود لطفي صقر وآية شوقي خاطر '
}

\section{الملخص العربي}

المقدمة: تعتبر الإصابة بسم العقرب مشكلة حقيقية للصحة العامة في جميع أنحاء العالم، وخاصة في شمال الصحراء الأفريقية. الهدف من هذه الدراسة: تقييم التغيرات في دلالات الدم وعلاقاتحا مع شدة التأثر بسم العقرب. بالإضافة إلى تقييم هذه التغييرات في دلالات الدم ومدى تغيرها بعد العلاج بالمصل المضاد لسم العقرب.

الطريقة: تضمنت دراسة مستقبلية بr مريضًا من كلا الجنسين المتعرضين لسم العقرب في مركز السموم الاكلينيكي بمستشفيات جامعة عين شمس في الفترة ما بين مايو 1 ا • ب إلى مايو 9 ا • r. تم تصنيف المرضى الي مجموعتين وفقا لدرجة الخطورة. المجموعة الأولى (البسيطة) والمجموعة الثانية (المعتدلة والشديدة). النتائج: أظهر مرضى المجموعة الثانية (المعتدلة والشديدة) زيادة في مستوى الهيموجلوبين وقيمة الهيماتوكريت وإجمالي عدد كرات الدم البيضاء بالمقارنة مع المجموعة الأولى (البسيطة). وكذلك أظهر مرضى المجموعة الثانية زيادة في قياس توزيع الصفائح الدمويّة، ومتوسط حجم الصفائح الدموية، ونسبة الخلايا الكبيرة للصفائح

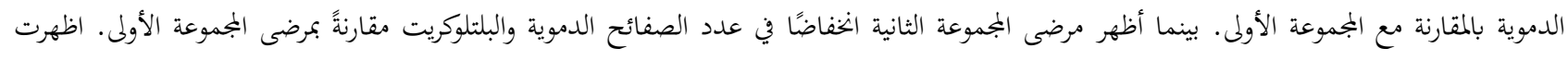
المجموعة الثانية انخفاض في قيمة الهيماتوكريت، العدد الكلي لكرات الدم البيضاء، عدد الصفائح الدموية البلتلوكريت وزمن التجلط الجزئي بعد تلقي المصل المضاد لسم العقرب.

الحلاصة: أظهرت النتائج التي توصلنا إليها أن عدد كرات الدم البيضاء ونسبة الصفائح الدموية الكبيرة وزمن التجلط الجزئي تعتبر أدوات مفيدة في التنبؤ بدرجة الاصابة الشديد بسم العقرب. وكذلك الهيماتوكريت، عدد كرات الدم البيضاء، عدد الصفائح الدموية البلتلوكريت وزمن البروثرومبين هي أدوات بسيطة لمتابعة 